\section{Spanish universities}

\section{New law leaves unsolved problems}

\section{Barcelona}

Although Spanish universities will benefit in many ways from the new law now coming into effect, many academics believe the legislation is too little, too late, or both. Even so, the university reform law, passed in 1983, is being implemented methodically; a new university structure should be in place by 1988 .

During this month, most universities have been electing their academic heads (presidents in US universities, vicechancellors in Britain), often with surprising results. Those standing for office have mostly been professors with a strong political background. The chief candidates for the post at the University of Barcelona were two members of the Catalan Parliament; after a close fight, Professor Bricall, an independent economist and a member of the socialist parliamentary group, defeated a communist professor of Greek. At the Polytechnic University of Catalania, on the other hand, a member of CDC (the nationalist Catalan party) defeated a candidate supported by socialist and communist professors.

Other Spanish universities have also found the elections to have had a political dimension, in part because of the political attention paid to university reform during the past few years, while the long overdue reform law was being hatched. Among the important changes are the decision that future appointments will be made more logically than under the previous system of oposiciones. In the words of $\mathrm{Sr} \mathrm{C}$. Virgili, "candidates will be judged by what they know and not what they are ignorant of".

At the same time, the autonomy of the universities is being strengthened after a long period (since the civil war) when they have been in a straitjacket, even to the extent that universities will be able to determine their own curriculum. Similarly, courses of study leading to the $\mathrm{PhD}$ degree are being consolidated, which will enhance their status. The present socialist government is providing strong financial support for the reforms and has enormously increased its support for university research.

Indeed, the Spanish parliament is about to approve a new package of legislation dealing with science, which is eagerly awaited and which will transform the administration of science in Spain. The law has been delayed by changes demanded by the Senate, but should be complete next month.

The reasons why not everybody is satisfied with the reforms go back for many years. Especially towards the end of the Franco regime, political activities tended to dominate the affairs of the universities; afterwards, despite active discussion of the need for university reform, the early democratic governments were unable to carry through legislation. And even now, some universities appear to provide a playground for future politicians or even a shelter for those who have failed in the parliamentary elections and are waiting for better times.

Moderate discontent is illustrated by the views of Professor A. Nieto, a former president of the Spanish research council, who says in article published by the March Foundation (Cuardernos Universitarios, no. 225) that the new law will not by itself solve the problems facing the Spanish universities. When the universities are governed by the rules of the parliamentary government, Nieto says, people are compelled to fight for power and to disregard the essential functions of the universities. What matters in academic life is therefore the number of votes a person controls, not his performance in teaching and research.

Nieto argues that a university may be governed either by the state or by society, but "never by its own professors, who should be the servants of the university, nor by its students, who are its beneficiaries". On autonomy, he says that no-

\section{Hydroengineering}

THE controversy over the GabcikovoNagymaros hydroelectric project on the Danube (see Nature 317, 9; 1985) continues to acquire international overtones. Since the Austrian government last year undertook to finance the construction work at Nagymaros in Hungary, the Austrian "greens" excused their government of "exporting" its environmental problems to Hungary. The Austrian greens therefore decided, according to their leader, Dr Gunther Nenning, to "export demorcratic, non-violent constitutional resistance" to Hungary. The first such attempt, a "protest walk" through Budapest on 8 February, was broken up by the police, but the greens, backed by their West German counterparts, seem determined to keep up the pressure, and hope to make Austrian involvement in Nagymaros a major issue in the forthcoming Austrian general election.

At the same time, attempts by the unofficial "Danube Circle" of Hungarian environmentalists to finance an "independent" survey of the possible consequences of the dam are attracting considerable attention in Sweden. The money for the survey would come from the "Right Livelihood Award", presented annually body knows what the effects would be because Spanish universities have never been, and are not now, autonomous, but he agrees that more autonomy might lead to "internal qualitative differentiation" within universities, with the result that some would excel over others.

As things are, the role of university professors as academic leaders is ambiguous and confused. For example, as the reform law is applied, the constitution of the committees appointed to fill vacant faculty positions enormously favours inbreeding; the students of the committee chairman are the most likely to succeed. Many academics fear that this state of affairs will hamper the improvement of research activity. Another worrying sign is the large number of the sons and daughters of middle-class families who move to the United States for their undergraduate studies. Has the turbulence of the 1970 s undermined people's faith in the universities?

Despondently, Nieto believes that change will come only from outside, "as a consequence of a profound change in the social and political mentality" of Spain, which he believes will not come quickly. But others recognize that the new law is a legal framework for reform, and look to Spain's accession to the European Community from the beginning of this year with great hope.

\title{
More controversy over Danube
}

by the Swedish parliament. The awards are conferred not on individuals but on groups. Since the Danube Circle is not recognized by the Hungarian government, it cannot import the prize money. Dr Janos Vargha, who represented the circle at the prize ceremony last December, has indicated that the members would pay any organization competent to carry out the survey, provided the survey would be independent. Representatives of the Right Livelihood Foundation have begun lobbying international figures for the Danube Circle to be allowed to use the money as they wish.

Western interest in the dam has not gone unmarked in the Comecon bloc. The project has been praised both as a joint Czechoslovak - Hungarian venture and as a major achievement of socialist cooperation. Officially, all environmental hazards of the dam have been foreseen and wellprovided for by surveys which include not only the Hungarian and Czechoslovak academies, but Soviet experts as well. This is the first time that direct Soviet involvement in the plans for the dam has been openly mentioned, and it has been widely interpreted as a direct response to growing Western interest. Vera Rich 